\title{
Synthesis of Human Bone Morphogenetic Protein-2 (hBMP-2) in E. coli Periplasmic Space: Its Characterization and Preclinical Testing
}

\author{
João E. Oliveira ${ }^{1}$, Miriam F. Suzuki ${ }^{1}{ }^{1}$, Renata Damiani ${ }^{2}$, Eliana R. Lima ${ }^{2}$, Kleicy C. Amaral ${ }^{1}$ (D), \\ Anderson M. S. Santos ${ }^{3}$, Geraldo S. Magalhães ${ }^{4}$ (D) Leonardo P. Faverani ${ }^{3}$ (D) Luís A. V. D. Pereira ${ }^{5}$ \\ and Paolo Bartolini ${ }^{1, *}$
}

check for

updates

Citation: Oliveira, J.E.; Suzuki, M.F.; Damiani, R.; Lima, E.R.; Amaral, K.C.; Santos, A.M.S.; Magalhães, G.S.; Faverani, L.P.; Pereira, L.A.V.D.; Bartolini, P. Synthesis of Human Bone Morphogenetic Protein-2 (hBMP-2) in E. coli Periplasmic Space: Its Characterization and Preclinical Testing. Cells 2021, 10, 3525. https:// doi.org/10.3390/cells10123525

Academic Editor: Sabine Bailly

Received: 1 September 2021

Accepted: 8 November 2021

Published: 14 December 2021

Publisher's Note: MDPI stays neutral with regard to jurisdictional claims in published maps and institutional affiliations.

Copyright: (C) 2021 by the authors. Licensee MDPI, Basel, Switzerland. This article is an open access article distributed under the terms and conditions of the Creative Commons Attribution (CC BY) license (https:/ / creativecommons.org/licenses/by/ $4.0 /)$.
1 Instituto de Pesquisas Energéticas e Nucleares, IPEN-CNEN, Av. Prof. Lineu Prestes 2242, São Paulo 05508-000, SP, Brazil; jeolivei@ipen.br (J.E.O.); mfsuzuki@ipen.br (M.F.S.); kleicy12@hotmail.com (K.C.A.)

2 Biosintesis P \& D, São Paulo 05508-000, SP, Brazil; redamiani@hotmail.com (R.D.); lima-eliana@hotmail.com (E.R.L.)

3 Department of Diagnosis and Surgery, School of Dentistry, Sao Paulo State University, UNESP, Araçatuba 16015-050, SP, Brazil; andersonmaikon@hotmail.com (A.M.S.S.); leonardo.faverani@unesp.br (L.P.F.)

4 Immunopathology Laboratory, Instituto Butantan, São Paulo 05503-900, SP, Brazil; Geraldo.magalhaes@butantan.gov.br

5 Department of Biochemistry and Tissue Biology, Institute of Biology, State University of Campinas, UNICAMP, Campinas 13083-970, SP, Brazil; lviolin@unicamp.br

* Correspondence: pbartoli@ipen.br

\begin{abstract}
Human BMP-2, a homodimeric protein that belongs to the TGF- $\beta$ family, is a recognized osteoinductor due to its capacity of inducing bone regeneration and ectopic bone formation. The administration of its recombinant form is an alternative to autologous bone grafting. A variety of E. coli-derived hBMP-2 has been synthesized through refolding of cytoplasmic inclusion bodies. The present work reports the synthesis, purification, and characterization of periplasmic hBMP-2, obtained directly in its correctly folded and authentic form, i.e., without the initial methionine typical of the cytoplasmic product that can induce undesired immunoreactivity. A bacterial expression vector was constructed including the DsbA signal peptide and the cDNA of hBMP-2. The periplasmic fluid was extracted by osmotic shock and analyzed via SDS-PAGE, Western blotting, and reversed-phase high-performance liquid chromatography (RP-HPLC). The purification was carried out by heparin affinity chromatography, followed by high-performance size-exclusion chromatography (HPSEC). HPSEC was used for qualitative and quantitative analysis of the final product, which showed $>95 \%$ purity. The classical in vitro bioassay based on the induction of alkaline phosphatase activity in myoblastic murine $\mathrm{C} 2 \mathrm{C} 12$ cells and the in vivo bioassay consisting of treating calvarial critical-size defects in rats confirmed its bioactivity, which matched the analogous literature data for hBMP-2.
\end{abstract}

Keywords: hBMP-2; periplasmic expression; calvarial critical-size defect; osteoinductor

\section{Introduction}

Human bone morphogenetic protein-2 (hBMP-2) was first discovered when Urist et al. established the biological basis of morphogenesis [1-3]. Its purification from demineralized bone matrix and definitive characterization were first performed by Reddi et al. [4-6].

hBMP-2 is a homodimeric cysteine-knot protein that belongs to the transforming growth factor- $\beta$ (TGF- $\beta$ ) family, whose structure is stabilized through dimerization and an additional intermolecular disulfide bond [7,8]. It was soon observed that hBMP-2 is one of the most efficient osteoinductors ever described, especially because of its capacity of inducing bone regeneration and ectopic bone formation in adult vertebrates. Its cloning 
and synthesis in $\mathrm{CHO}$ cells were first carried out at the Genetic Institute of Cambridge, MA, USA $[9,10]$, administration of the recombinant form being an alternative to autologous bone grafting, used in a variety of orthopedic and dental applications, such as spinal fusions and oral surgery, and in the repair of bone, cartilage, tendons, and ligaments [11-15]. In particular, it has been demonstrated that the application of recombinant hBMP-2, together with an absorbable collagen sponge (ACS), induces new bone formation in mandibular and cleft palate defects, whose results have been compared to those of autogenous bone grafts [16,17].

One of the most important and widely used recombinant preparation of hBMP-2 is Infuse $^{\circledR}$ from Medtronic (Minneapolis, MN, USA), obtained from CHO cells and even considered to be a type of international reference preparation for clinical use $[18,19]$. A variety of $E$. coli-derived preparations obtained through solubilization and refolding of cytoplasmic inclusion bodies also demonstrated good biological activity [8,13,20-23]. Different in vitro and in vivo studies also proved the comparable osteoinductive capacity and clinical efficacy of these preparations [24-27].

In the present work, the synthesis of hBMP-2 was achieved in the periplasmic space of genetically modified E. coli, which provides the naturally refolded protein in its authentic form.

After osmotic shock, the periplasmic fluid was extensively purified via three chromatographic steps, followed by a physical-chemical and immunological characterization via RP-HPLC, HPSEC, SDS-PAGE and Western blotting, in comparison with the well-known cytoplasmic Met-hBMP-2 from GenScript (Piscataway, NJ, USA). The classical in vitro and in vivo bioassays, based respectively on alkaline phosphatase induction in myoblastic murine cells $\mathrm{C} 2 \mathrm{C} 12$ and on new bone formation in calvarial critical-size defects in rats, confirmed the osteoinductive properties of our hBMP-2.

A preliminary pilot-scale production of this hBMP-2 was also carried out under wellcontrolled bioreactor conditions, showing the real possibility of obtaining this protein in useful amounts.

\section{Materials and Methods}

\subsection{Construction and Testing of the Expression Vector}

The pUC57-derived plasmid containing the restriction sites EcoRI, NdeI, BamHI, the bacterial signal sequence of DsbA (disulfide bond formation protein A), and hBMP-2 cDNA (NCBI Reference Sequence: AF040249.1-Homo sapiens bone morphogenetic protein-2 gene, complete cds), was commercially synthesized by GenScript (Piscataway, NJ, USA) providing the plasmid pUC57-DsbA-BMP-2 (Figure 1).

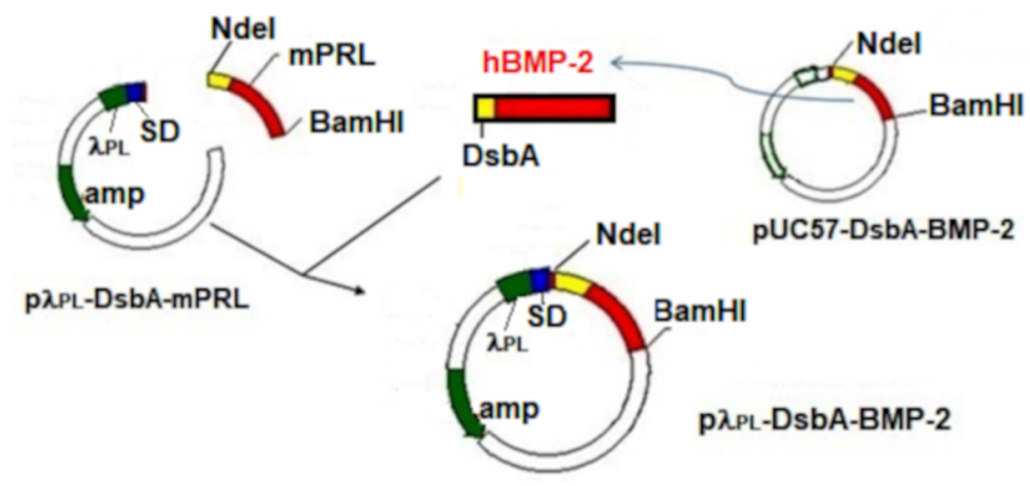

Figure 1. Construction scheme of the bacterial expression vector $\mathrm{p} \lambda_{\mathrm{PL}}-\mathrm{DsbA}-\mathrm{BMP}-2$ for the periplasmic expression of authentic hBMP-2.

The fragment DsbA-hBMP-2 was withdrawn from this plasmid by NdeI and BamHI digestion and purified via agarose gel (1\%) electrophoresis in TAE (Tris-acetate EDTA) buffer. Another fragment including the $\lambda_{\mathrm{PL}}$ promoter, the Shine-Dalgarno (SD) sequence, and the gene for ampicillin resistance $\left(A m p^{R}\right)$ was obtained via NdeI, BamHI digestion 
from the $\mathrm{p} \lambda_{\mathrm{PL}}$-DsbA-mPRL expression vector, previously constructed by the same research group [28]. The ligation reaction between the two fragments was carried out using T4 DNA ligase (New England Biolabs Inc., Ipswich, MA, USA), incubating overnight at $4{ }^{\circ} \mathrm{C}$. The molar ratio between the first fragment (insert) and the second fragment (vector) was 5:1. The correct construction of the final expression vector $\mathrm{p} \lambda_{\mathrm{PL}}$-DsbA-BMP-2 (2966 bp) was checked in $1 \%$ agarose gel, by BamHI and NdeI digestion, providing the two expected fragments of $2559 \mathrm{bp}$ and $407 \mathrm{bp}$. After transforming competent bacteria (DH5 $\alpha$ ) with the ligation product, 10 colonies were obtained, which were tested by PCR for the presence of $\mathrm{p} \lambda_{\mathrm{PL}}$-DsbA-BMP-2, using the following two primers: sense GGCGCATATGAAAAAGATTTGGCTGG and antisense ATTAGGATCCTACTAGCGACACCCAC. Two colonies were found to be positive, the PCR product being sequenced at the Human Genome and Stem Cell Research Center (HUG-CELL) of the Institute of Biosciences of the University of São Paulo (São Paulo, Brazil), confirming the correct sequence in comparison with pUC57-hBMP-2 and with the theoretical hBMP-2 sequence, utilizing the BioEdit Sequence Alignment Editor Software [29].

\subsection{Heparin Affinity and HPSEC Purification}

The W3110 E. coli strain, transformed with $\mathrm{p} \lambda \mathrm{P}_{\mathrm{L}}-\mathrm{DsbA-BMP}-2$ and containing the thermosensitive repressor of transcription cIts, was grown in Erlenmeyer flasks, and the periplasmic fluid was extracted by osmotic shock, as previously described [30]. The first hBMP-2 purification step was carried out on this periplasmic fluid by heparin affinity chromatography, at room temperature, introducing significant modifications in the method described by Vallejo et al. [13]. As an example, the concentrated periplasmic fluid ( 80 $\mathrm{mL})$,

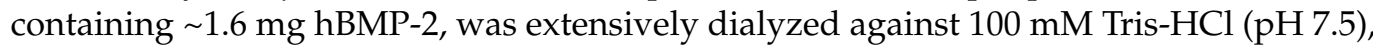
overnight, using a membrane SnakeSkin Dialysis Tubing (Thermo Scientific, Rockford, IL, USA), $22 \mathrm{~mm}$ dry I.D. with a $3.5 \mathrm{kDa}$ cut off, and passed through a $0.45 \mu \mathrm{m}$-pore-size filter, hydrophilic PVDF, 47 mm-diameter membrane GV Durapore ${ }^{\circledR}$ (Merck Millipore, Cork, Ireland). The dialyzed fluid was applied to a $5 \mathrm{~mL}$ HiTrap Heparin HP column (GE Healthcare Bio-Science AB, Uppsala, Sweden), which had been equilibrated with 5 column volumes $(\mathrm{CV})$ of dialysis buffer. After washing the column with $5 \mathrm{CV}$ of the same dialysis buffer, the monomeric and dimeric forms of hBMP-2 were eluted via a 0 to $0.3 \mathrm{M} \mathrm{NaCl}$ gradient in a $50 \mathrm{~mL}$ elution volume. The eluted fractions containing dimeric hBMP-2 $(\sim 3 \mathrm{~mL})$ were applied (6 fractions of $500 \mu \mathrm{L})$ to preparative HPSEC, obtaining finally a total of $574 \mu \mathrm{g}$ of purified hBMP-2 in $2 \mathrm{~mL}$ (total yield $=36 \%$ ), which was stored at $-70{ }^{\circ} \mathrm{C}$.

\subsection{SDS-PAGE and Western Blotting}

Periplasmic hBMP-2 and samples from the purification steps were analyzed by $15 \%$ polyacrylamide gel electrophoresis (SDS-PAGE) under non-reducing conditions, as previously described, Coomassie Brilliant Blue G-250 being used for the staining [31]. For Western blotting, the semi-dry transfer technique on nitrocellulose membrane was used, with anti-hBMP-2 affinity-purified rabbit IgG, 1:2000 (Biovision, Milpitas, CA, USA) and goat anti-rabbit IgG conjugated to horseradish peroxidase (1:5000). Proteins were visualized with Luminata Forte (Merck, Burlington, MA, USA) on CL-Xposure ${ }^{\mathrm{TM}}$ Film (Thermo Scientific, Rockford, IL, USA).

\subsection{Analytical Reversed-Phase High-Performance Liquid Chromatography (RP-HPLC)}

RP-HPLC was performed on a Jupiter C4 column (Phenomenex, Torrance, CA, USA), $250 \mathrm{~mm} \times 4.6 \mathrm{~mm}$ I.D., $5 \mu \mathrm{m}$ particle size, and $300 \AA$ pore size, connected to a guard column cartridge $(4 \mathrm{~mm} \times 3 \mathrm{~mm}$ I.D., $3 \mu \mathrm{m}$ particle size $)$ in a Shimadzu model SCL-10A apparatus. Elution was carried out at $30^{\circ} \mathrm{C}$ with UV detection at a wavelength of $220 \mathrm{~nm}$. For the gradient, two solutions were used: solution A, TFA 1:1000 in $\mathrm{H}_{2} \mathrm{O}$, and solution $\mathrm{B}$, $10 \% \mathrm{~A}$ in acetonitrile. The linear gradient used for hBMP-2 elution went from $30 \% \mathrm{~B}(v / v)$ to $60 \% \mathrm{~B}(v / v)$ over $30 \mathrm{~min}$, followed by an isocratic step with $60 \%$ B for $5 \mathrm{~min}$. 


\subsection{High-Performance Size-Exclusion Chromatography (HPSEC)}

HPSEC was used for analytical and preparative purposes, employing a G2000 SW column $(600 \mathrm{~mm} \times 7.5 \mathrm{~mm}$ I.D., particle size of $10 \mu \mathrm{m}$ and pore size of $125 \AA$ from Tosoh Bioscience (Montgomeryville, PA, USA), in a Shimadzu model SCL-10 A apparatus. UV absorbance detection was at $220 \mathrm{~nm}$, with a flow rate of $1.0 \mathrm{~mL} / \mathrm{min}$, using $0.15 \mathrm{M} \mathrm{NaCl}$ in $0.02 \mathrm{M}$ sodium phosphate buffer, $\mathrm{pH} 7.0$, as the mobile phase for isocratic elution.

\subsection{In Vitro hBMP-2 Bioassay in C2C12 Cells}

The in vitro biological activity of hBMP-2 was determined by measuring the induction of alkaline phosphatase activity in murine myoblastic $\mathrm{C} 2 \mathrm{C} 12$ cells [32]. Briefly, $\mathrm{C} 2 \mathrm{C} 12$ cells (from ATCC ${ }^{\circledR}$-CRL-1722) were grown in DMEM medium with $2 \mathrm{mM}$ L-glutamine, $0.1 \mathrm{mM}$ non-essential amino acids, $1 \mathrm{mM}$ sodium pyruvate, and $10 \%$ fetal bovine serum at $37^{\circ} \mathrm{C}$ and $5 \% \mathrm{CO}_{2}$. One hundred microliters of $\mathrm{C} 2 \mathrm{C} 12$ cells $\left(3 \times 10^{5}\right.$ cells $\left./ \mathrm{mL}\right)$ was added to a 96-well plate, and the medium was replaced after $24 \mathrm{~h}$ with fresh medium, $2 \%$ calf serum, and different concentrations of hBMP-2, each concentration being analyzed in duplicate. After $72 \mathrm{~h}$, the cells were lysed in $0.2 \mathrm{~mL}$ of buffer A (0.1 M glycerol, $\mathrm{pH} 9.6,1 \% \mathrm{NP}-40$, $1 \mathrm{mM} \mathrm{MgCl}_{2}$, and $1 \mathrm{mM} \mathrm{ZnCl}_{2}$ ). Then, $50 \mu \mathrm{L}$ of cell lysates was mixed with $150 \mu \mathrm{L} 0.3 \mathrm{mM}$ p-nitrophenyl-phosphate (Sigma-Aldrich, Saint Louis, MO, USA) in buffer A, incubating at $37^{\circ} \mathrm{C}$ for $30 \mathrm{~min}$. Alkaline phosphatase activity was determined by reading the absorbance at $405 \mathrm{~nm}$ with a Multiskan EX Microplate Reader (Thermo Electron Corporation, Beverly, MA, USA).

\subsection{Large-Scale Fermentation under Controlled Bioreactor Conditions}

Fed-batch bioreactor experiments were carried out in a $20 \mathrm{~L}$ Laboratory Bioreactor (New MBR, Zurich, Switzerland), adding $100 \mu \mathrm{g} / \mathrm{mL}$ of ampicillin [30]. The bioreactor operated at $\mathrm{pH} 7.2$ and dissolved $\mathrm{O}_{2}$ was maintained above $20 \%$ of air saturation by increasing the agitation speed from 200 to $900 \mathrm{rpm}$ and adding 1 volume of air per volume of medium per minute (VVM), to avoid $\mathrm{O}_{2}$ limitation. A complex culture medium, a two- or four-fold concentrate of the HKSII medium reported by Jensen and Carlsen [33], was used. For inoculation, $10 \%$ of the initial total volume (i.e., $500 \mathrm{~mL}$ ) of $\mathrm{LB}$ medium containing the transformed $\mathrm{W} 3110$ strain that had reached $0.5 \mathrm{~A}_{600}$ units was used, the culture being maintained at $30{ }^{\circ} \mathrm{C}$ until activation. The carbon source (glucose in this case) addition was started at a biomass concentration corresponding to $5 \mathrm{~A}_{600}$ units, the feed rate being adjusted to the desired value and kept constant until the end of the cultivation. Activation at $42{ }^{\circ} \mathrm{C}$ started when $\mathrm{A}_{600}$ approached a plateau. The glucose feeding rates, when not specified differently, were $3.6 \mathrm{gL}^{-1} \mathrm{~h}^{-1}$ and $5.4 \mathrm{gL}^{-1} \mathrm{~h}^{-1}$ during the activation step.

\subsection{In Vivo Bioassay for the Determination of the Osteoinductive Potential by Treating Calvarial Critical-Size Defects in Rats}

The in vivo study was approved by the local ethics committee for the use of animals (\# 00285-2019) and followed the guidelines for animal research [34]. Twelve male rats (Rattus novergicus albinus, Wistar), six months old, weighing between 250 and $300 \mathrm{~g}$, were submitted to a bilateral critical-size defect in the calvarias. The rats were kept in a cage (3 per cage), in an environment with a controlled cycle of light (12 h light-dark), controlled temperature $\left(22 \pm 2{ }^{\circ} \mathrm{C}\right)$, and food and water ad libitum, except in the preoperative $8 \mathrm{~h}$, when they underwent fasting.

The animals were randomly divided into four groups, according to the material used to cover the defect. i.e., NC Group: just blood clot (negative control); ACS Group: absorbable collagen sponge alone; INF Group: ACS with commercial rhBMP-2 (Infuse ${ }^{\circledR}$ Bone GraftMedtronic, Memphis, TN, USA); hBMP-2 Biosintesis Group: collagen membrane with our bacterial hBMP-2.

The amount of added hBMP-2 was $2.5 \mu \mathrm{g} /$ defect for the Infuse ${ }^{\circledR}$ and $13.5 \mu \mathrm{g} /$ defect for the hBMP-2 Biosintesis groups, a difference that approximately reflected the difference 
in the in vitro bioactivities between Infuse ${ }^{\circledR}$ and hBMP-2 GenScript found in a previous work [31].

The sample size was determined via the software SigmaPlot 12.0 (Exakt Graphs and Data Analysis, San Jose, California, USA), based on data for newly formed bone area from the study by Nakamura et al. [35], which showed a mean difference of 1.77 and a standard deviation of 0.57 , with an alpha of 0.05 . Accordingly, five defects per group would be enough to obtain a power test of $95 \%$, but, since a bilateral defect was adopted, six defects per group were performed.

\subsubsection{Surgical Procedure}

After fasting for $8 \mathrm{~h}$, the animals were sedated with ketamine $(50 \mathrm{mg} / \mathrm{kg})$ and xylazine $\left(5 \mathrm{mg} / \mathrm{kg}\right.$ ) intramuscularly and received local anesthesia (Mepiadre100 ${ }^{\circledR}, \mathrm{DFL}$, Rio de Janeiro, RJ, Brazil) in the area to be operated. Trichotomy and antisepsis (Degerming and Topic Polyvinyl Pyrrolidone Iodine) were performed on the calvaria region. A " $\mathrm{V}$ " access, with the apex in the anterior region of the calvaria, was made to expose the parietal region, followed by osteotomy on both parietal bones with a trephine, creating a critical-size defect of five millimeters in diameter. According to the groups (ACS, INF, and hBMP2 Biosintesis), the defects were covered or not with any material, with only the blood clot remaining in the negative control (NC). The defects were finally covered by the flap and sutured with Nylon 5.0 (Mononylon, Ethicon, Johnson Prod., São José dos Campos, $\mathrm{SP}$, Brazil). All animals received a single dose of antibiotic intramuscularly $(0.2 \mathrm{mg} / \mathrm{kg}$; Pentabiotic-Zoetis ${ }^{\circledR}$, Bauru, SP, Brazil).

At 60 days after surgery, all animals were euthanized with an overdose of sodium thiopental $150 \mathrm{mg} / \mathrm{kg}$, intraperitoneally, and the calvarias was collected and stored in $10 \%$ formaldehyde for $48 \mathrm{~h}$, followed by histological and histometric analysis.

\subsubsection{Histological and Histometric Analyses}

After $48 \mathrm{~h}$ in formalin solution, the samples were washed for $12 \mathrm{~h}$ in water and decalcified during 8 weeks in ethylenediaminetetraacetic acid. The samples were dehydrated in alcohol $(70-100 \%)$, diaphanized in xylol, and embedded in paraffin. Five micron longitudinal tissue sections were obtained. Hematoxylin and eosin staining was used for histological assessment. The images were obtained on an optical microscope (Leica Microsystems, Heidelberg, Germany) from the central area of the bone defect. The histometric analysis was performed by an independent and blinded examiner (A.M.S.S.) using the Image J, version 1.53f 25; Software for Image Processing and Image Analysis, NIH, USA, 2020. The Newly formed Bone Area (NBA- $\mu \mathrm{m}^{2}$ ) was measured. The analysis was performed at two different times (at least 15 days between each analysis) by the same examiner. The Kappa test showed a high level of agreement $(\mathrm{k}=0.90)$.

\subsubsection{Statistical Analysis}

The quantitative data for NBF were analyzed to test homogeneity through the ShapiroWilk test. The non-parametric one-way Kruskal-Wallis test followed by the StudentNewman-Keuls post-test was applied with a level of significance of 5\% in SigmaPlot 12.0 software (Exakt Graphs and Data Analysis, San Jose, CA, USA).

\section{Results}

\subsection{Expression of $h B M P-2$ in the Periplasm}

After testing the correct sequence of the $\mathrm{p} \lambda_{\mathrm{PL}}$-DsbA-hBMP-2 expression vector and the size and presence of the different components, the main objective was to prove hBMP-2 expression in the periplasm of the W3110 strain. Figure 2A shows the SDS-PAGE analysis of the periplasmic fluid, after cultivation at $30{ }^{\circ} \mathrm{C}$ and $42{ }^{\circ} \mathrm{C}$ of the transformed and untransformed (negative control) W3110 strain. It is important to note that the presence of the temperature-sensitive repressor (cIts) should potentially stop hBMP-2 synthesis at $30{ }^{\circ} \mathrm{C}$, favoring bacterial growth, then allowing its maximum expression at $42{ }^{\circ} \mathrm{C}$, with 
repressor deactivation. Unfortunately, this approach proved to be inconclusive due to the presence of numerous protein bands of difficult interpretation. The only clear result was related to the sole presence of the dimeric form of the reference preparation of met-hBMP-2 $(\sim 26 \mathrm{kDa})$ in wells 2 and 7. Protein bands close to this position were observed in all samples, including the negative control.
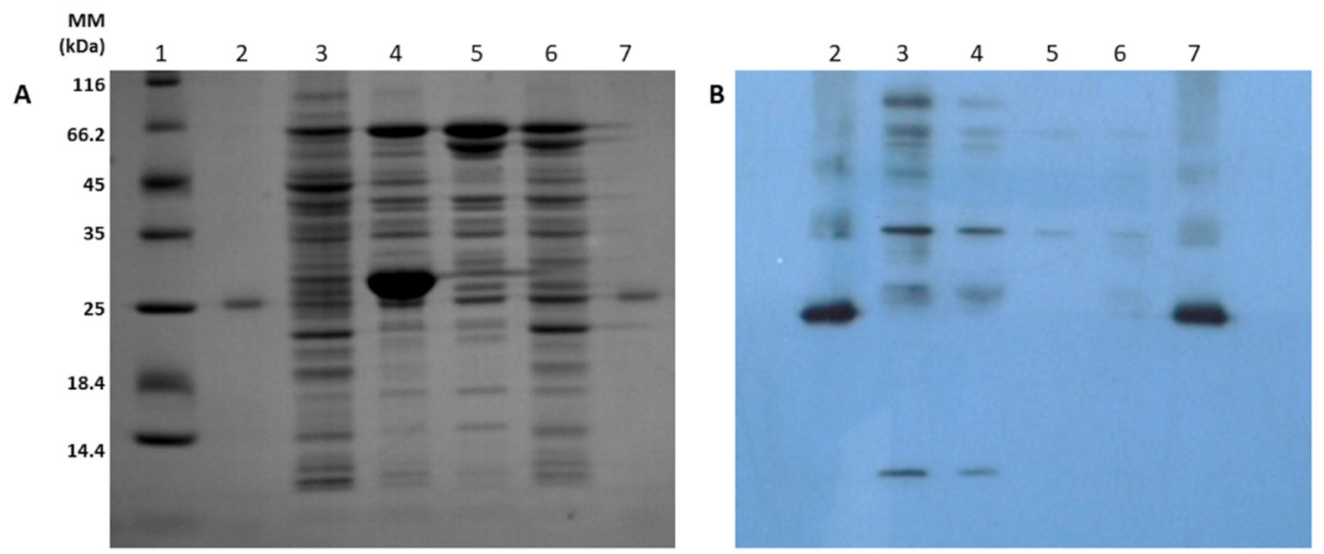

Figure 2. (A) SDS-PAGE analysis of periplasmic fluid obtained with the W3110 strain + repressor gene at $30{ }^{\circ} \mathrm{C}$ and $42{ }^{\circ} \mathrm{C}$. (1) Molecular marker, (2) met-hBMP-2 standard from GenScript, (3) W3110 periplasmic fluid at $42{ }^{\circ} \mathrm{C}$, (4) W3110 periplasmic fluid at $30^{\circ} \mathrm{C}$, (5) W3110 negative control at $30^{\circ} \mathrm{C}$, (6) W3110 negative control at $42{ }^{\circ} \mathrm{C}$, (7) met-hBMP-2 standard from GenScript. (B) Western blot analysis obtained under the same conditions described in (A).

In contrast, the corresponding Western blot in Figure 2B provided much more information. Thus, the reference preparation from GenScript (wells 2 and 7) was clearly mainly dimeric, but it showed at least three polymeric forms and absolutely no monomer. The dimeric form of our hBMP-2 appeared a little above the reference and was about 2 times more intense at $42{ }^{\circ} \mathrm{C}$. However, there were numerous polymeric or aggregated forms, in the regions of $35-38 \mathrm{kDa}$ and $60-80 \mathrm{kDa}$, all of which were more intense at $42{ }^{\circ} \mathrm{C}$, together with the clear and unexpected presence of the monomer $(\sim 13 \mathrm{kDa})$. We therefore concluded that the repressor was indeed working, but not very efficiently. The fact that the dimeric form of hBMP-2 migrated a little above the dimeric form of met-hBMP-2 might be due to a structural and conformational difference caused by the absence of the initial methionine. Concerning the implementation of this assay, it is of interest to emphasize that it was quite difficult to find a good working anti-hBMP-2 antibody. Good antigen-antibody reaction after Western blotting was only obtained thanks to an affinity-purified anti-hBMP-2 rabbit $\operatorname{IgG}(1: 2000)$ from Biovision.

For completeness, it was deemed necessary to confirm the presence of hBMP-2 in W3110 periplasm by employing a different technique. This was done by using RP-HPLC, a chromatographic technique in which the retention time $\left(t_{R}\right)$ of a given protein depends directly on its hydrophobicity. Figure 3 shows the superimposition of three RP-HPLC chromatograms, run on the same day ("super compare"). The black chromatographic trace corresponds to the reference preparation, which defines exactly the position of hBMP-2 $\left(t_{R}=17.4 \mathrm{~min}\right)$, while the two chromatographic traces below correspond to the W3110 strain, harboring the vector $\lambda_{\mathrm{PL}}-\mathrm{DsbA}-\mathrm{BMP}-2$, activated at $42{ }^{\circ} \mathrm{C}$ (red trace) and $30{ }^{\circ} \mathrm{C}$ (blue trace), respectively. The identity of our periplasmic hBMP-2 was thus confirmed, and again, the peak area obtained at $42{ }^{\circ} \mathrm{C}$ was approximately $2-3$ times larger than that obtained at $30^{\circ} \mathrm{C}$. 


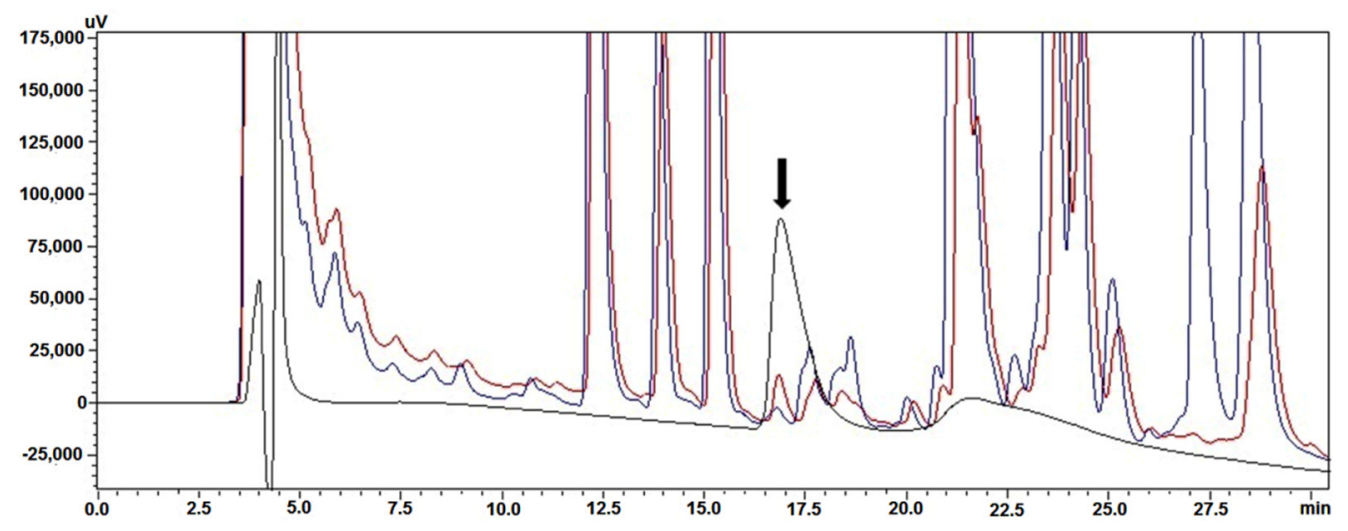

Figure 3. RP-HPLC analysis comparing hBMP-2 GenScript (black chromatographic trace) with the results using the repressor at $30{ }^{\circ} \mathrm{C}$ (blue trace) and at $42{ }^{\circ} \mathrm{C}$ (red trace). The arrow indicates the position of hBMP-2.

A similar comparison was also carried out via HPSEC after the first purification step on a heparin column, considering that this type of chromatography, based on molecular mass, normally represents the best quantifying technique. Figure 4A presents the chromatogram of our partially purified product, while Figure 4B shows the chromatogram obtained with the product derived from the untransformed W3110 strain (negative control) and submitted to the same purification process, which obviously lacks the hBMP-2 peak. On the same day, the reference preparation from GenScript presented $t_{R}=23.24 \mathrm{~min}$.

The second purification step was based on the same HPSEC, run in preparative mode, and the chromatogram of the obtained product is shown in Figure 5, where the black trace is purified hBMP-2, and the red trace corresponds to the reference preparation. Again, the $t_{R}$ were remarkably similar: $23.36 \mathrm{~min}$ and $23.24 \mathrm{~min}$ for hBMP-2 Biosintesis and hBMP-2 GenScript, respectively. This HPSEC-eluted product, that had undergone three purification steps (Heparin-affinity + HPSEC-1 + HPSEC-2), was considered to be the final product.

Table 1 reports the results of the purification processes up to the first HPSEC. Total protein $(\mu \mathrm{g} / \mathrm{mL})$ was determined via the classical assay based on the bicinchoninic acid assay (BCA); in the case of met-BMP-2 GenScript, the $5 \mu \mathrm{g}$ declared value was based on the nominal value. This preparation is in fact provided in vials with the following declaration: "it contains $1 \mathrm{mg}$ lyophilized product, with $>95 \%$ purity, in dimeric form ( 26 kDa) and biologically active for its capacity to induce alkaline phosphatase in C2C12 cells". Some recommendations concerning the poor stability of the product are also provided [31]. The quantity of hBMP-2 $(\mu \mathrm{g} / \mathrm{mL})$ was determined by HPSEC versus a standard protein repeatedly quantified on this column, and the specific activity was calculated as absorbance per microgram $\left(\mathrm{A}_{405} / \mu \mathrm{g}\right)$, after determining the biological activity in C2C12 cells. The latter parameter provided a potency of $98 \%$ for our product in comparison with the reference preparation.

Table 1. Purity and potency increase during hBMP-2 purification.

\begin{tabular}{cccccc}
\hline $\begin{array}{c}\text { Purification } \\
\text { Step }\end{array}$ & $\begin{array}{c}\text { Total Protein } \\
(\mu \mathrm{g} / \mathrm{mL})\end{array}$ & $\begin{array}{c}\text { hBMP-2 } \\
(\mu \mathrm{g} / \mathrm{mL})\end{array}$ & $\begin{array}{c}\text { Mass Fraction } \\
(\mathbf{\%})\end{array}$ & $\begin{array}{c}\text { ALP Activity *** } \\
\left(\mathbf{A}_{\mathbf{4 0 5}}\right)\end{array}$ & $\begin{array}{c}\text { ALP Specific Activity } \\
\left(\mathbf{A}_{\mathbf{4 0 5}} / \boldsymbol{\mu g} / \mathbf{m L}\right)\end{array}$ \\
\hline Periplasmic fluid & 2196 & 0.03 & 0.001 & 1.149 & $0.5 \times 10^{-3}$ \\
\hline Heparin affinity & 220 & 14.13 & 6.42 & 2.792 & 1.006 \\
\hline HPSEC & 1.6 & 1.29 & 80.62 & 3.2 & $629 \times 10^{-3}$ \\
\hline $\begin{array}{c}\text { GenScript } \\
\text { hBMP-2 }\end{array}$ & 5.00 & 3.70 & 74.00 & $640 \times 10^{-3}$ \\
\hline
\end{tabular}

\footnotetext{
* Determined by BCA; ${ }^{* *}$ Determined by HPSEC; ${ }^{* * *}$ Determined by C2C12 assay.
} 

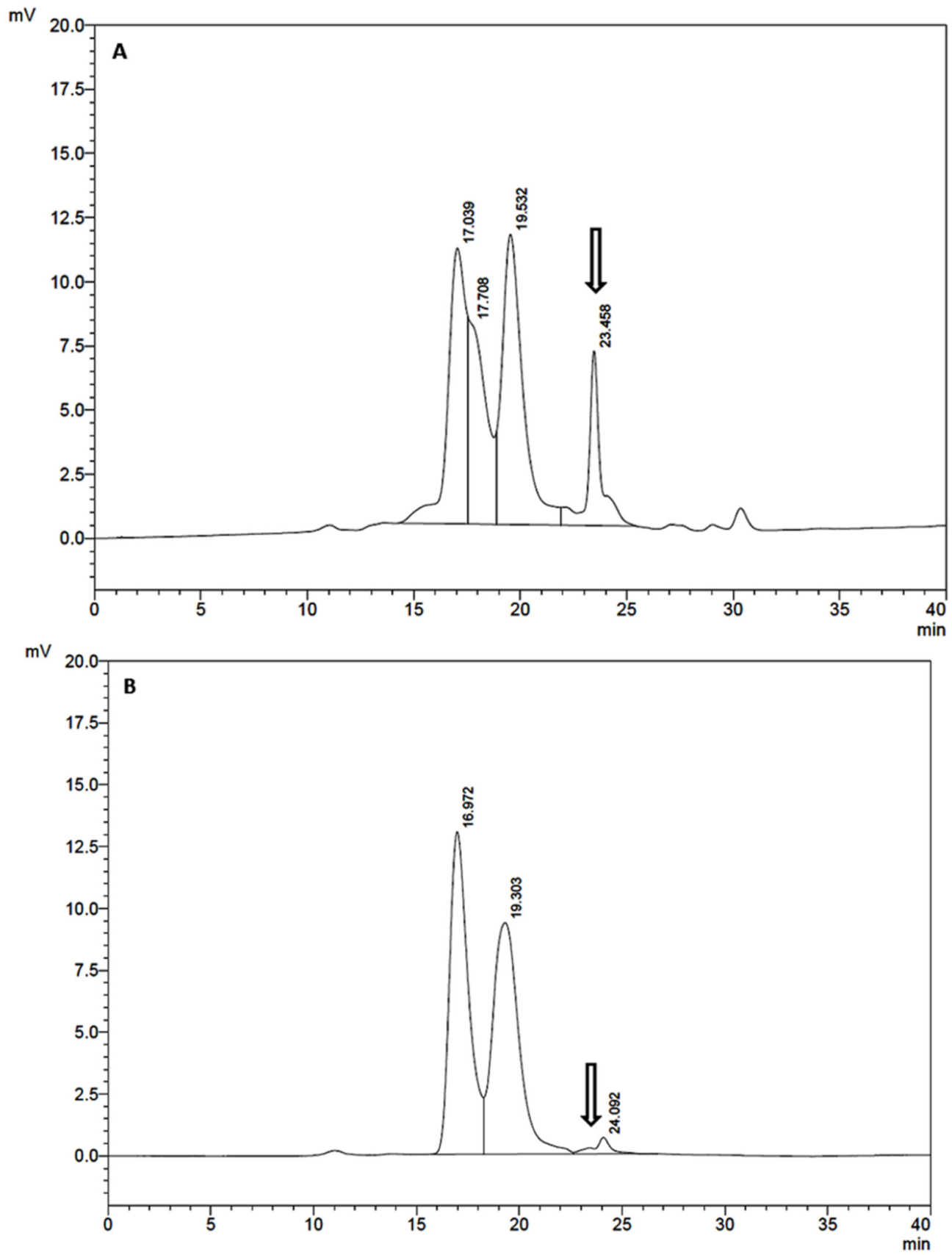

Figure 4. HPSEC analysis comparing the heparin affinity-eluted product obtained with the W3110 $\mathrm{p} \lambda_{\mathrm{PL}}$-DsbA-BMP-2-producing strain (A) and the W3110 negative control (B). The arrow indicates the position of hBMP-2.

\subsection{In Vitro Bioassay in $\mathrm{C} 2 \mathrm{C} 12$ Cells}

An inter-preparation, inter-laboratory comparison was also performed, based on the biological assay in $\mathrm{C} 2 \mathrm{C} 12$ cells. As we can see in Figure 6, three graphs are presented. The first (Figure 6A) is adapted from [13], analyzing their renatured and purified cytoplasmic product, the second (Figure 6B) represents our analysis carried out on the GenScript product, while the third (Figure 6C) represents our analysis carried out on our purified product. The related dose-response equations are the following:

(A) $\mathrm{Y}=0.533 \mathrm{X}+0.024(\mathrm{n}=4 ; \mathrm{r}=0.991 ; p<0.01)$

(B) $\mathrm{Y}=0.637 \mathrm{X}-0.011(\mathrm{n}=5 ; \mathrm{r}=0.997 ; p<0.001)$

(C) $\mathrm{Y}=0.659 \mathrm{X}+0.038(\mathrm{n}=5 ; \mathrm{r}=0.947 ; p<0.02)$ 


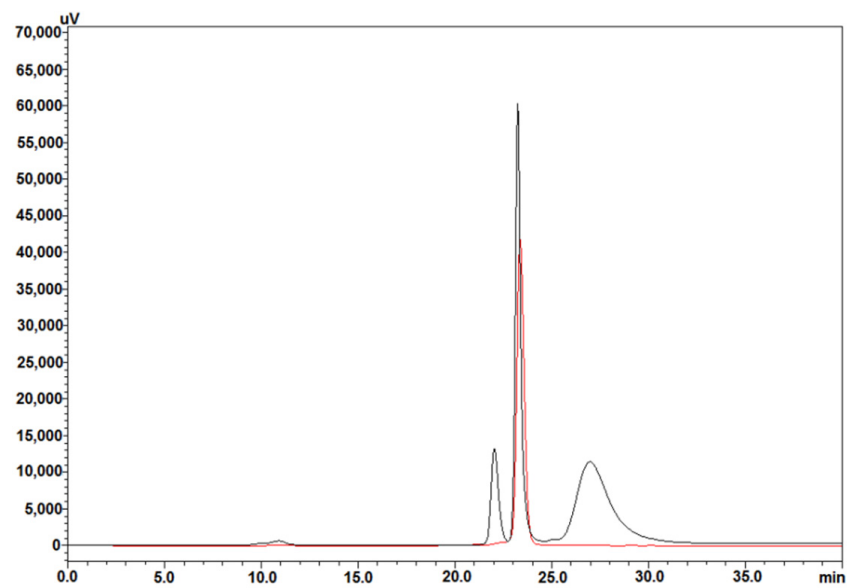

Figure 5. HPSEC analysis comparing hBMP-2 Biosintesis (red trace) after three purification steps (HiTrap Heparin HP, HPSEC-1, and HPSEC-2) with the hBMP-2 reference preparation from GenScript (black trace).
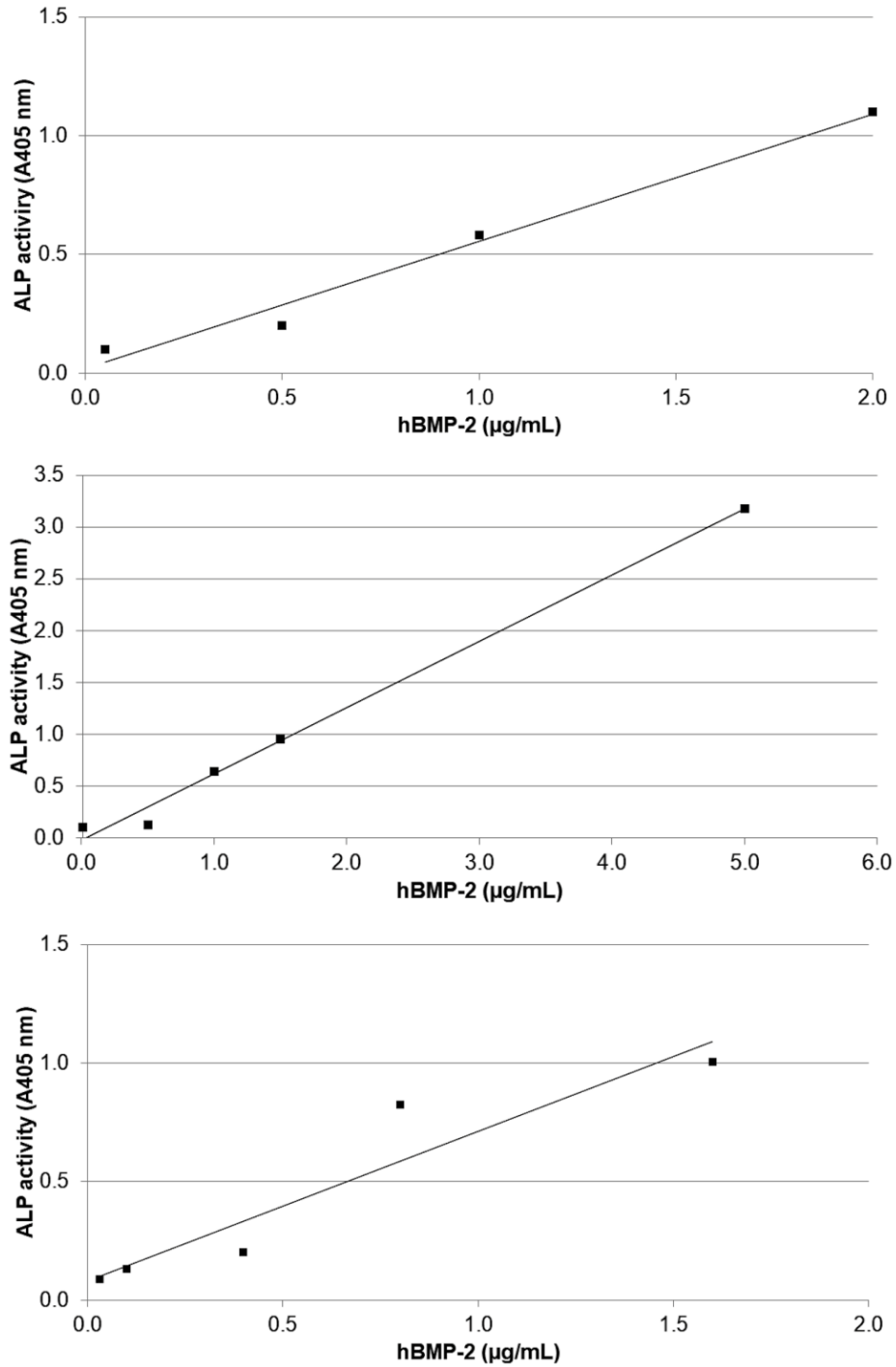

Figure 6. In vitro biological activity determined by alkaline phosphatase induction in $\mathrm{C} 2 \mathrm{C} 12$ cells. (A) Data adapted from [13]; (B) standard met-hBMP-2, GenScript; (C) purified hBMP-2 Biosintesis. 
It should be emphasized that the data of Vallejo et al. [13] were used with the consent of Dr. Ursula Rinas and that the equation of this curve was calculated by us based on the published data.

\subsection{Fermentation of $h B M P-2$ in a Bioreactor}

The specific and volumetric expression provided by the $\lambda_{\mathrm{PL}}-\mathrm{Dsb} \mathrm{A}-\mathrm{BMP}-2$ vector in the W3110 strain + repressor, in Erlenmeyer, were $0.16 \pm 0.05 \mu \mathrm{g} / \mathrm{mL} / \mathrm{A}_{600}$ and $0.71 \pm 0.37 \mu \mathrm{g} / \mathrm{mL}$ $(\mathrm{n}=4)$, respectively (Table 2). The same fermentation was then carried out in a $20 \mathrm{~L}$ bioreactor, under controlled conditions of $\mathrm{pH}$, stirring, and dissolved oxygen level, using rich medium and glucose addition at an initial volume of $5 \mathrm{~L}$, as described by Jensen and Carlsen [33]. Figure 7 shows a comparison with a repetition of an optimal experiment carried out by our research group for bioreactor production of hGH [30]. In the previous work, the $\mathrm{hGH}$ volumetric expression was $94.8 \mathrm{mg} / \mathrm{L}$, while the same strain, under the same conditions, provided an even higher value, i.e., $123 \mathrm{mg} / \mathrm{L}$, in the current work. The best performance for our hBMP-2, obtained with Jensen $4 \times$ broth, was only $9 \mathrm{mg} / \mathrm{L}$, pointing to the necessity of additional investigation and process optimization.

Table 2. Specific and volumetric expression of hBMP-2.

\begin{tabular}{|c|c|c|c|c|c|}
\hline $\begin{array}{c}\text { Specific } \\
\text { Expression } \\
\left(\mu \mathrm{g} / \mathrm{mL} / \mathbf{A}_{600}\right)\end{array}$ & $\begin{array}{c}\text { Specific } \\
\text { Expression } \\
\text { MEAN } \pm \text { SD }\end{array}$ & $\begin{array}{c}\text { Final } \\
\text { Biomass } \\
\left(\mathbf{A}_{600}\right)\end{array}$ & $\begin{array}{c}\text { Final } \\
\text { Biomass } \\
\text { MEAN } \pm \text { SD }\end{array}$ & $\begin{array}{l}\text { Volumetric } \\
\text { Expression } \\
(\mathrm{mg} / \mathrm{L})\end{array}$ & $\begin{array}{c}\text { Volumetric } \\
\text { Expression } \\
\text { MEAN } \pm \text { SD }\end{array}$ \\
\hline 0.20 & \multirow{4}{*}{$0.16 \pm 0.05$} & 4.46 & \multirow{4}{*}{$4.25 \pm 1.43$} & 0.89 & \multirow{4}{*}{$0.71 \pm 0.37$} \\
\hline 0.16 & & 2.68 & & 0.42 & \\
\hline 0.19 & & 6.08 & & 1.14 & \\
\hline 0.10 & & 3.76 & & 0.37 & \\
\hline
\end{tabular}

\subsection{In Vivo Bioassay Based on Rat Calvarias Critical-Size Defect Treatment}

The histological analysis showed a complete calvaria defect closure at 60 days for the Infuse ${ }^{\circledR}$ (INF) and hBMP-2 Biosintesis groups. The major difference between the groups regarded the bone volume and the blood vessels (Figure 8). The negative control (NC) group showed the thinnest bone height, with few blood vessels in the Newly formed Bone Area (NBA). In the absorbable collagen sponge, the ACS group, a slight increase in bone height and a small amount of blood vessels were noted, but some connective tissue remained in the central area, and there were ACS fragments on the edge of the newly formed bone.

The hBMP-2 groups (Infuse ${ }^{\circledR}$ and hBMP-2 Biosintesis) showed almost twice as much bone height as the control group. Large vessels were observed in the central area of both groups, with a larger newly formed bone area.

The histometric analysis for newly formed bone area (NBA) showed 1,006 $\pm 45 \mu \mathrm{m}^{2}$ for the Infuse ${ }^{\circledR}$ group, $781 \pm 147 \mu \mathrm{m}^{2}$ for the hBMP-2 Biosintesis group, $439 \pm 22 \mu \mathrm{m}^{2}$ for the ACS group, and $374 \pm 42 \mu \mathrm{m}^{2}$ for the NC group (Figure 9). Concerning NBA, statistical analysis showed that the two hBMP-2 groups were significantly different $(p<0.005$ or $p<0.001)$ in comparison with the two control groups. Our preparation did, however, exhibit a slightly lower osteoinduction compared to Infuse ${ }^{\circledR}(p=0.027)$. 
A

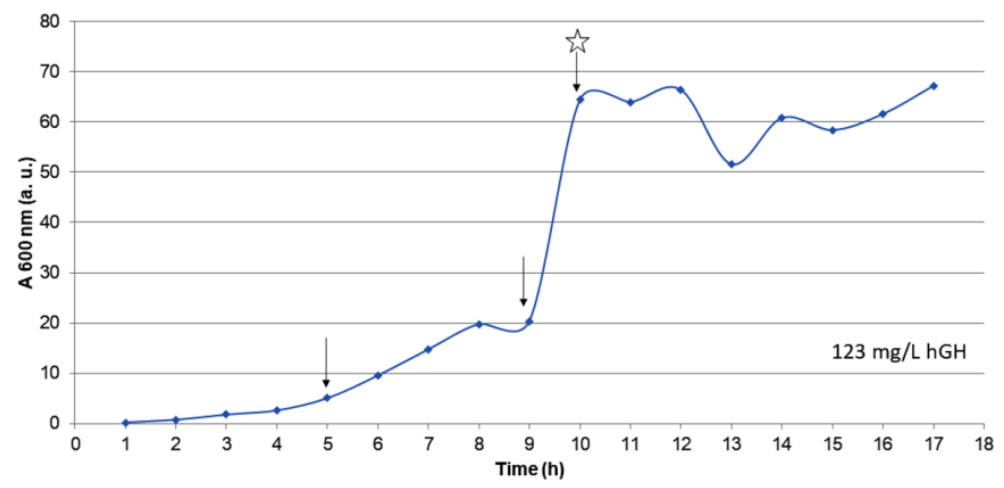

B

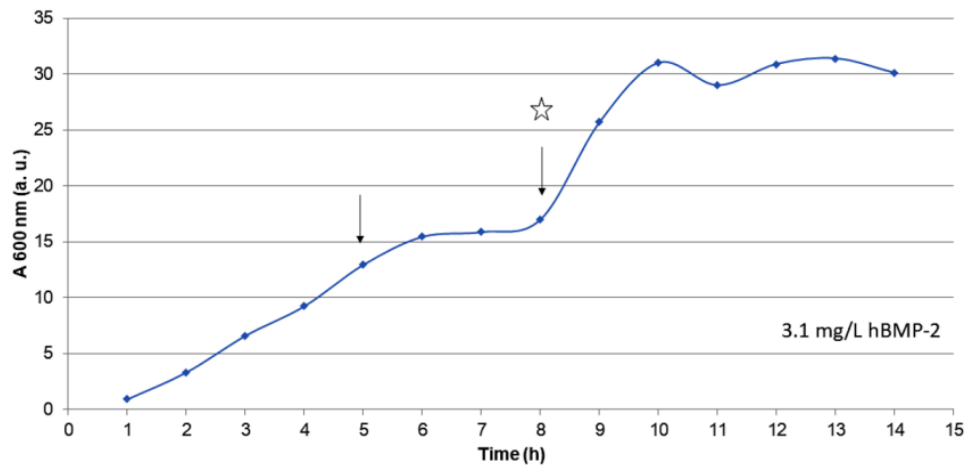

C

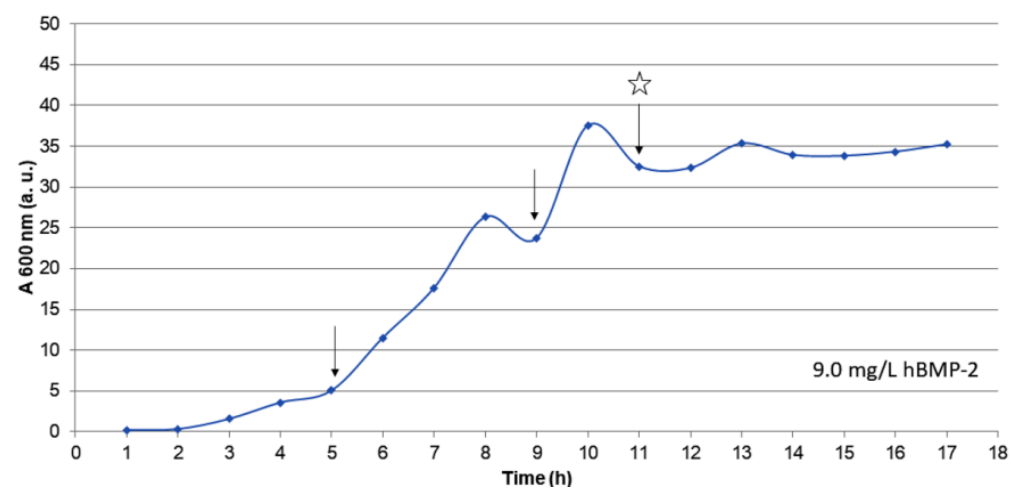

Figure 7. Bioreactor production with $5 \mathrm{~L}$ of broth. (A) W3110- $\lambda_{\mathrm{PL}}-\mathrm{hGH}-\mathrm{Rep} / 42{ }^{\circ} \mathrm{C}$ with Jensen $4 \times$ broth, (B) W3110- $\lambda_{\mathrm{PL}}-\mathrm{hBMP}-2-\mathrm{Rep} / 42{ }^{\circ} \mathrm{C}$ with Jensen $2 \times$ broth, and (C) W3110- $\lambda_{\mathrm{PL}}-\mathrm{hBMP}-$ 2-Rep $/ 42{ }^{\circ} \mathrm{C}$ with Jensen $4 \times$ broth. The arrows indicate the addition of glucose (fed-batch) at $\mathrm{A}_{600} \geq 5$ units, and the star an increase of temperature from $30{ }^{\circ} \mathrm{C}$ to $42{ }^{\circ} \mathrm{C}$. 


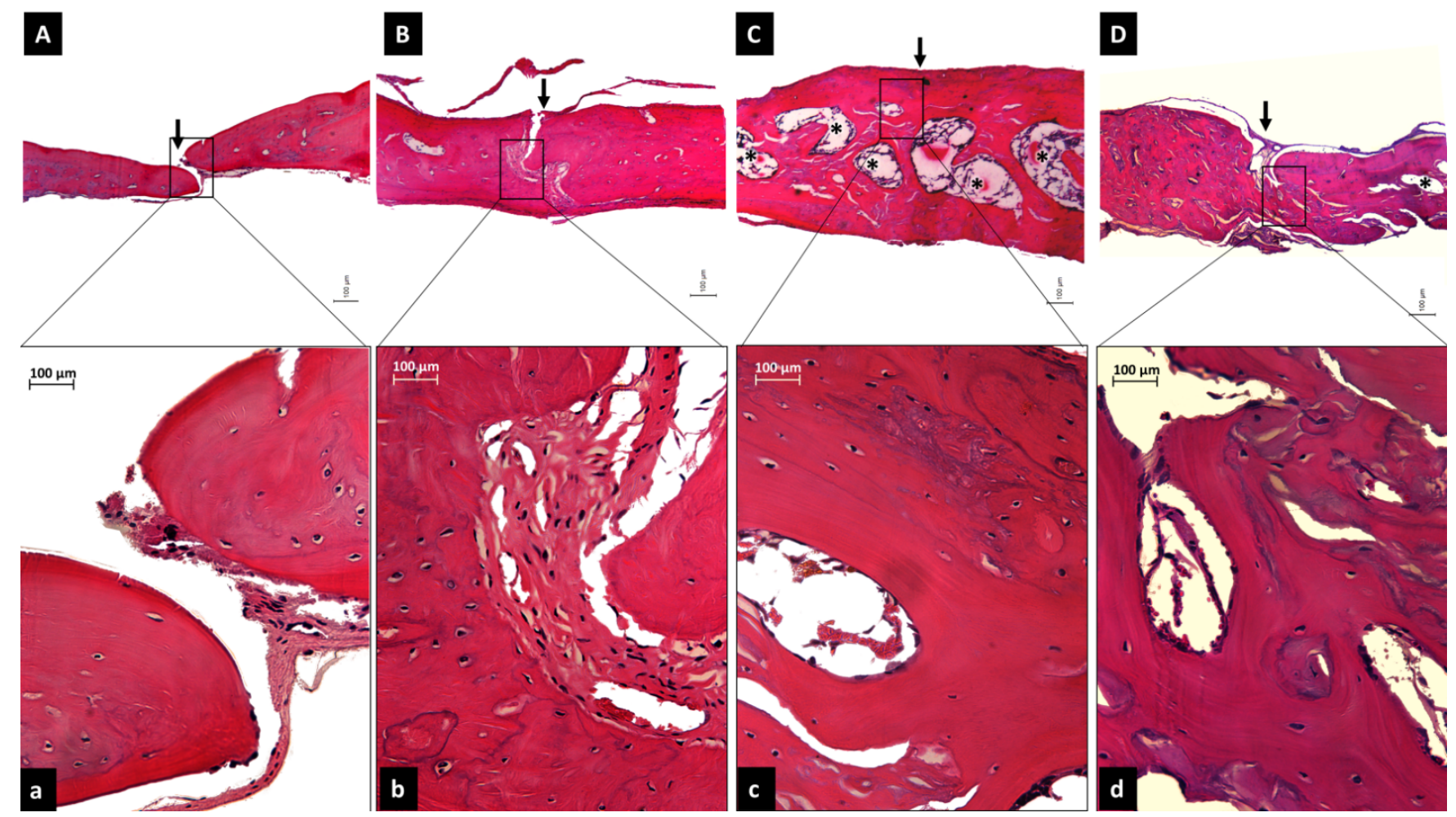

Figure 8. Histologic aspect of the central area of bone defects in all groups at 60 days (hematoxylin and eosin staining). The negative control, NC group (A), and absorbable collagen sponge group, ACS, (B) showed non-closure of the bone defect (black arrow) and remaining connective tissue, while the Infuse ${ }^{\circledR}(\mathbf{C})$ and hBMP-2 Biosintesis groups (D) showed the closure of the defects (black arrow) and bigger vessels in the defect area $\left(^{*}\right)$; moreover, peripheral connective tissue was noticed in the hBMP-2 Biosintesis group. Higher magnification $(\mathbf{a}-\mathbf{d})$ of the areas within the black frames show the amount of newly formed tissue. NC (a) and ACS (b) showed a gap filled with connective tissue while (c,d) showed a significant formation of bone, with more bone for the Infuse ${ }^{\circledR}$ group (c). Scale bars: $100 \mu \mathrm{m}$.

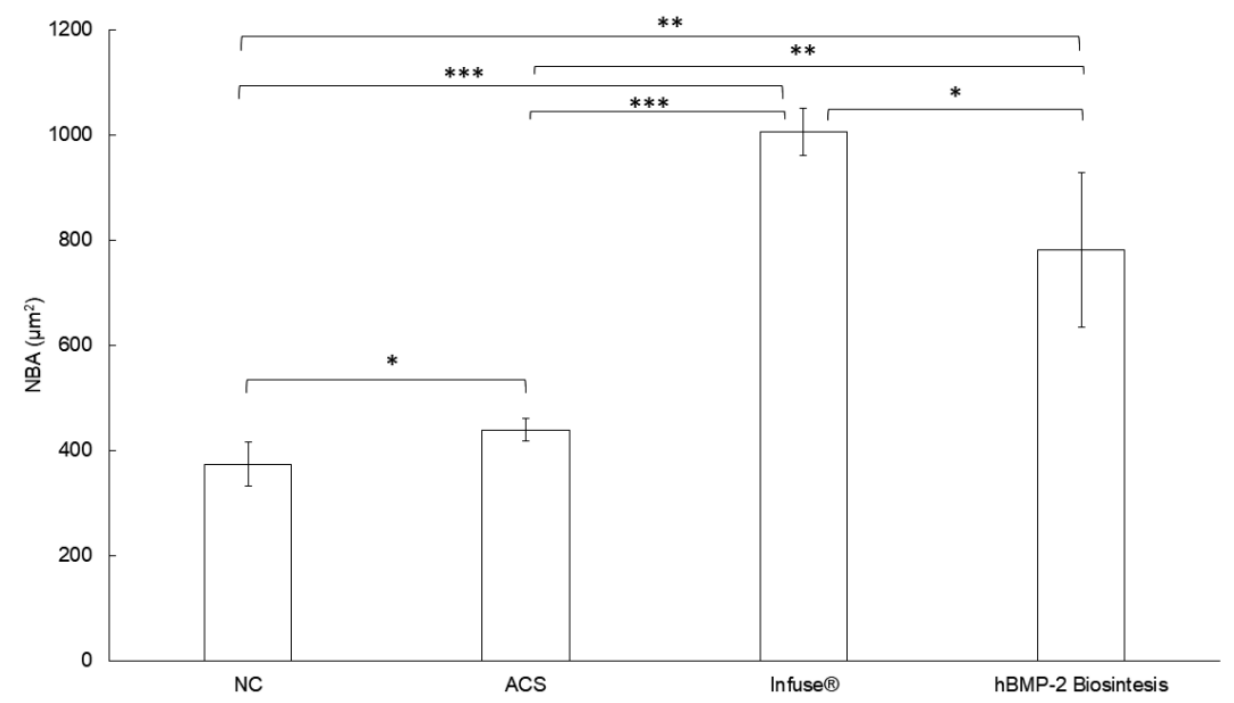

Figure 9. Histometric data for Newly formed Bone Area (NBA), 60 days after surgery, for the four groups analyzed. ${ }^{*} p<0.05 ;{ }^{* *} p<0.005 ;{ }^{* * *} p<0.001$.

\section{Discussion}

hBMP-2, one of the most efficient osteoinductors ever described, has now been successfully synthesized in E. coli periplasm in its natural, correctly folded, and authentic form, 
without the initial methionine, typical of cytoplasmic products, that frequently induces an undesired immunological reaction. For this purpose, an original expression vector based on hBMP-2 cDNA, the $\lambda_{\mathrm{PL}}$ promoter, the DsbA signal sequence, and the $\mathrm{Amp}^{\mathrm{R}}$ gene was constructed and used to transform the E. coli W3110 strain. The identity of hBMP-2 was confirmed via Western blotting, RP-HPLC, and HPSEC by comparison with the cytoplasmic dimeric form of met-hBMP-2 from GenScript. Given that the bioactive form of this protein is the dimer, our efforts were directed to its purification through three steps, a HiTrap heparin affinity chromatography and two HPSECs, with the final product showing $>95 \%$ purity.

On the other hand, the molar masses of the most intense periplasmic structures showing immunologic activity (Figure $2 \mathrm{~B}$ ) are around $35-38 \mathrm{kDa}$ and $60-80 \mathrm{kDa}$. This deserves further investigation considering that, as pointed out by Israel et al. (1992), CHOderived hBMP-2 contains a predominant bioactive protein of $30 \mathrm{kDa}$. Of course, $\mathrm{CHO}$ cells are known to glycosylate proteins, while normal E. coli cells do not. In this context, we confirmed that some of these homodimeric forms are probably variants that differ only as a result of proteolytic processing at their amino termini $[10,31]$. Indeed, in MALDI-TOF-MS, our hBMP-2 exhibited a constant peak of $\sim 31 \mathrm{kDa}$ (results not shown). This may be due to the fact that the periplasmic bands are formed naturally, while the cytoplasmic hBMP-2 bands are constructed in order to obtain the homodimer. As stated by Quaas et al. [8], the intricate disulfide-bond pattern of the complex cysteine-knot scaffold was not present in the inclusion bodies with embedded disulfide-linked hBMP-2 but was formed later during classical refolding of the reduced protein under appropriate redox conditions. Therefore, it would not be a surprise to find that some of these high-molecular-weight periplasmic structures have good biological activity.

As a preliminary bioactivity determination, the classical in vitro assay based on induced alkaline phosphatase activity in murine myoblastic C2C12 cells was applied to our product, using the GenScript preparation for comparison. The slopes of the two dose-response curves, considered to be an indication of relative potency, were very similar: $0.637 \mathrm{~A}_{405} / \mu \mathrm{g}$ and $0.697 \mathrm{~A}_{405} / \mu \mathrm{g}$ for the GenScript preparation and for our product, respectively. These potencies were, moreover, not so different from that derived from an analogous renatured and purified cytoplasmic hBMP-2 $\left(0.533 \mathrm{~A}_{405} / \mu \mathrm{g}\right)$, reported by Vallejo et al. [13] and already mentioned in previous work [31]. It is particularly noteworthy that, after two purification steps, the specific activity of our product was already very close to that of the GenScript preparation.

The use of an in vivo biological assay based on the osteoinductive potential of hBMP2 for the treatment of calvarial critical-size defects in rats is, in our opinion, one of the most valuable aspects of our work. This assay, derived from a recent publication of Nakamura et al. [35], is widely considered to be a type of "gold standard" for testing the bone regeneration capacity of osteoinductors. Numerous pre-clinical studies have been conducted using different carriers in a variety of animal models, as described in a recent and extensive review [36]. The assay is particularly relevant because it employs two critical-size defects produced in the same animal, each one $5 \mathrm{~mm}$ in diameter, distant from each other by at least $2 \mathrm{~mm}$ : one defect serves as the standard, while the other evaluates the efficacy of the product under test. Critical size means that the defect cannot be closed spontaneously by new bone tissue unless a bone generation procedure is performed. The calvarial model is thus considered to be highly efficient for evaluating bone regeneration, due to its convenience, reproducibility, and low invasiveness, as well as the fact that it is a bone area that is not subjected to any strenuous activity [37-40]. In this context, it should be noted, that most studies that synthesized hBMP-2 in bacteria relied primarily on the alkaline phosphatase in vitro assay rather than evaluating the in vivo bioactivity of their preparation $[8,13,20,22,32,41]$.

Our product was evaluated by comparison with CHO-derived Infuse ${ }^{\circledR}$, which can be considered an international reference preparation for clinical use, with a collagen sponge control, and with a negative control. Statistically, both hBMP-2 preparations 
were significantly different from the two controls, and hBMP-2 Biosintesis presented a slightly lower potential in comparison with Infuse ${ }^{\circledR}$. While literature data [24-27] report a comparable clinical efficacy of E. coli-derived versus glycosylated CHO-derived hBMP-2, in our hands these products showed different potencies, not only in the in vivo bioassay but also in the in vitro bioassay in $\mathrm{C} 2 \mathrm{C} 12$ cells, as described in previous work [31]. Prohibitive prices limited our analyses to only two commercially available products: $\mathrm{CHO}$-derived Infuse ${ }^{\circledR}$ and cytoplasmic met-hBMP-2 from GenScript.

The experience of our research group in producing E. coli-derived recombinant proteins allowed us to expeditiously run a preliminary large-scale fermentation process under controlled bioreactor conditions, with the W3110 strain transformed with the $\mathrm{p} \lambda_{\mathrm{PL}}-\mathrm{DsbA}$ BMP-2 expression vector. The model we followed was the one previously employed for $\mathrm{hGH}$ production, starting from a similar vector construction and the same bacterial strain and fermentation process: $\mathrm{p} \lambda_{\mathrm{PL}}-\mathrm{DsbA}-\mathrm{hGH}$, in the W3110 strain harboring the transcription repressor gene cIts. The fed-batch fermentation, with glucose addition and activation at $42{ }^{\circ} \mathrm{C}$, based on the $\mathrm{p} \lambda_{\mathrm{PL}}$-DsbA-BMP-2 expression vector, unfortunately provided a low yield, pointing to the need for further studies and improvement. Nonetheless, with a $150 \mathrm{~L}$ bioreactor, our laboratory has the potential to obtain $1.35 \mathrm{~g}$ of hBMP-2 in just a single fermentation process, which is relatively satisfactory, considering that this protein is an extremely high added-value product used clinically at the microgram level.

Author Contributions: Conceptualization, P.B.; methodology, P.B., G.S.M., L.A.V.D.P., and L.P.F.; formal analysis, A.M.S.S., M.F.S., J.E.O., R.D., E.R.L., and K.C.A.; resources, R.D.; data curation, P.B.; writing-original draft preparation, P.B. and L.A.V.D.P.; writing-review and editing, P.B., J.E.O., and M.F.S.; supervision, P.B.; project administration, R.D.; funding acquisition, P.B. All authors have read and agreed to the published version of the manuscript.

Funding: This work was supported by the São Paulo State Research Foundation-FAPESP, São Paulo, Brazil-Project n. 2015/15446-0 and n. 2016/24724-6.

Institutional Review Board Statement: Not applicable.

Informed Consent Statement: Not applicable.

Data Availability Statement: The data presented in this study are available on request from the corresponding author.

Acknowledgments: The authors wish to thank the wonderful teams from the Biotechnology Center (IPEN-CNEN/SP), from Biosintesis P\&D, and from UNESP School of Dentistry (Araçatuba, SP) for all support and collaboration.

Conflicts of Interest: The authors declare no conflict of interest.

\section{References}

1. Urist, M.R. Bone: Formation by autoinduction. Science 1965, 150, 893-899. [CrossRef]

2. Urist, M.R.; Strates, B.S. The classic: Bone morphogenetic protein. Clin. Orthop. Relat. Res. 2009, 467, 3051-3062. [CrossRef] [PubMed]

3. Strates, B.S.; Kirkpatrick, S.J.; Heffner, J.E.; Urist, M.R. Effect of chemical modification of tyrosine residues on bone morphogenesis. Biochem. J. 1971, 125, 367-369. [CrossRef] [PubMed]

4. Reddi, A.H.; Huggins, C.B. Citrate and alkaline phosphatase during transformation of fibroblasts by the matrix and minerals of bone. Proc. Soc. Exp. Biol. Med. 1972, 140, 807-810. [CrossRef]

5. Sampath, T.K.; Reddi, A.H. Dissociative extraction and reconstitution of extracellular matrix components involved in local bone differentiation. Proc. Natl. Acad. Sci. USA 1981, 78, 7599-7603. [CrossRef]

6. Sampath, T.K.; Muthukumaran, N.; Reddi, A.H. Isolation of osteogenin, an extracellular matrix-associated, bone-inductive protein, by heparin affinity chromatography. Proc. Natl. Acad. Sci. USA 1987, 84, 7109-7113. [CrossRef] [PubMed]

7. Scheufler, C.; Sebald, W.; Hulsmeyer, M. Crystal structure of human bone morphogenetic protein-2 at 2.7 A resolution. J. Mol. Biol. 1999, 287, 103-115. [CrossRef]

8. Quaas, B.; Burmeister, L.; Li, Z.P.; Nimtz, M.; Hoffmann, A.; Rinas, U. Properties of dimeric, disulfide-linked rhBMP-2 recovered from E. coli derived inclusion bodies by mild extraction or chaotropic solubilization and subsequent refolding. Process. Biochem. 2018, 67, 80-87. [CrossRef] 
9. Wozney, J.M.; Rosen, V.; Celeste, A.J.; Mitsock, L.M.; Whitters, M.J.; Kriz, R.W.; Hewick, R.M.; Wang, E.A. Novel regulators of bone formation: Molecular clones and activities. Science 1988, 242, 1528-1534. [CrossRef]

10. Israel, D.I.; Nove, J.; Kerns, K.M.; Moutsatsos, I.K.; Kaufman, R.J. Expression and characterization of bone morphogenetic protein-2 in Chinese hamster ovary cells. Growth Factors 1992, 7, 139-150. [CrossRef]

11. Boden, S.D. Biology of lumbar spine fusion and use of bone graft substitutes: Present, future, and next generation. Tissue Eng. 2000, 6, 383-399. [CrossRef]

12. Kirker-Head, C.A. Potential applications and delivery strategies for bone morphogenetic proteins. Adv. Drug Deliv. Rev. 2000, 43, 65-92. [CrossRef]

13. Vallejo, L.F.; Brokelmann, M.; Marten, S.; Trappe, S.; Cabrera-Crespo, J.; Hoffmann, A.; Gross, G.; Weich, H.A.; Rinas, U. Renaturation and purification of bone morphogenetic protein-2 produced as inclusion bodies in high-cell-density cultures of recombinant Escherichia coli. J. Biotechnol. 2002, 94, 185-194. [CrossRef]

14. Wikesjo, U.M.; Qahash, M.; Huang, Y.H.; Xiropaidis, A.; Polimeni, G.; Susin, C. Bone morphogenetic proteins for periodontal and alveolar indications; biological observations-clinical implications. Orthod. Craniofac. Res. 2009, 12, 263-270. [CrossRef]

15. De Freitas, R.M.; Susin, C.; Tamshiro, W.M.S.C.; de Souza, J.A.C.; Marcantonio, C.; Wilkesiö, U.M.; Pereira, L.A.V.D.; Marcantonio, E., Jr. Histological analysis and gene expression profile following augmentation of the anterior maxilla using rhBMP-2/ACS versus autogenous bone graft. J. Clin. Periodontol. 2016, 43, 1200-1207. [CrossRef] [PubMed]

16. Herford, A.S.; Boyne, P.J. Reconstruction of mandibular continuity defects with bone morphogenetic protein-2 (rhBMP-2). J. Oral Maxillofac Surg. 2008, 66, 616-624. [CrossRef] [PubMed]

17. Dickinson, B.P.; Ashley, R.K.; Wasson, K.L.; O’Hara, C.; Gabbay, J.; Heller, J.B.; Bradley, J.P. Reduced morbidity and improved healing with bone morphogenic protein-2 in older patients with alveolar cleft defects. Plast. Reconstr. Surg. 2008, 121, 209-217. [CrossRef]

18. Ong, F.R.; Bouazza-Marouf, K. Evaluation of bone strength: Correlation between measurements of bone mineral density and drilling force. Proc. Inst. Mech. Eng. H J. Eng. Med. 2000, 214, 385-399. [CrossRef]

19. Even, J.; Eskander, M.; Kang, J. Bone morphogenetic protein in spine surgery: Current and future uses. J. Am. Acad. Orthop. Surg. 2012, 20, 547-552. [CrossRef]

20. Ruppert, R.; Hoffmann, E.; Sebald, W. Human bone morphogenetic protein 2 contains a heparin-binding site which modifies its biological activity. Eur. J. Biochem. 1996, 237, 295-302. [CrossRef]

21. Bessho, K.; Konishi, Y.; Kaihara, S.; Fujimura, K.; Okubo, Y.; Iizuka, T. Bone induction by Escherichia coli -derived recombinant human bone morphogenetic protein-2 compared with Chinese hamster ovary cell-derived recombinant human bone morphogenetic protein-2. Br. J. Oral Maxillofac. Surg. 2000, 38, 645-649. [CrossRef]

22. Long, S.; Truong, L.; Bennett, K.; Phillips, A.; Wong-Staal, F.; Ma, H. Expression, purification, and renaturation of bone morphogenetic protein-2 from Escherichia coli. Protein Expr. Purif. 2006, 46, 374-378. [CrossRef]

23. Lee, J.Y.; Musgrave, D.; Pelinkovic, D.; Fukushima, K.; Cummins, J.; Usas, A.; Robbins, P.; Fu, F.H.; Huard, J. Effect of bone morphogenetic protein-2-expressing muscle-derived cells on healing of critical-sized bone defects in mice. J. Bone Joint Surg. Am. 2001, 83, 1032-1039. [CrossRef] [PubMed]

24. Yano, K.; Hoshino, M.; Ohta, Y.; Manaka, T.; Naka, Y.; Imai, Y.; Sebald, W.; Takaoka, K. Osteoinductive capacity and heat stability of recombinant human bone morphogenetic protein-2 produced by Escherichia coli and dimerized by biochemical processing. $J$. Bone Miner. Metab. 2009, 27, 355-363. [CrossRef] [PubMed]

25. Harada, Y.; Itoi, T.; Wakitani, S.; Irie, H.; Sakamoto, M.; Zhao, D.; Nezu, Y.; Yogo, T.; Hara, Y.; Tagawa, M. Effect of Escherichia coli-produced recombinant human bone morphogenetic protein 2 on the regeneration of canine segmental ulnar defects. J. Bone Miner. Metab. 2012, 30, 388-399. [CrossRef] [PubMed]

26. Lee, J.; Lee, E.M.; Yoon, J.; Chung, S.M.; Prasad, H.; Susin, C.; Wikesjö, U.M.E. Comparative study of Chinese hamster ovary cell versus Escherichia coli-derived Bone Morphogenetic Protein-2 using the critical size supraalveolar peri-implant defect model. J. Periodont. 2013, 84, 415-422. [CrossRef] [PubMed]

27. Jin, Y.Z.; Zheng, G.B.; Lee, J.H. Escherichia coli BMP-2 showed comparable osteoinductivity with Chinese hamster ovary derived BMP-2 with demineralized bone matrix as carrier. Growth Factors. 2019, 37, 85-94. [CrossRef] [PubMed]

28. Suzuki, M.F.; Arthuso, F.S.; Oliveira, J.E.; Oliveira, N.A.; Goulart, H.R.; Capone, M.V.; Ribela, M.T.; Bartolini, P.; Soares, C.R. Expression, purification, and characterization of authentic mouse prolactin obtained in Escherichia coli periplasmic space. Biotechnol. Appl. Biochem. 2012, 59, 178-185. [CrossRef] [PubMed]

29. Hall, T.A. BioEdit: A user-friendly biological sequence alignment editor and analysis program for Windows 95/98/NT. Nucl. Acids. Symp. Ser. 1999, 41, 95-98.

30. Soares, C.R.J.; Ueda, E.K.M.; Oliveira, T.L.; Gomide, F.I.C.; Heller, S.R.; Bartolini, P. Distinct human prolactin (hPRL) and growth hormone $(\mathrm{hGH})$ behavior under bacteriophage lambda PL promoter control: Temperature plays a major role in protein yields. $J$. Biotechnol. 2008, 133, 27-35. [CrossRef]

31. Suzuki, M.F.; Oliveira, J.E.; Damiani, R.; Lima, E.R.; Amaral, K.C.; Santos, A.M.S.; Magalhães, G.S.; Faverani, L.P.; Pereira, L.A.V.D.; Silva, F.M.; et al. Human bone morphogenetic protein-2 (hBMP-2) characterization by physical-chemical, immunological and biological assays. AMB Express 2020, 10, 34. [CrossRef]

32. Kirsch, T.; Nickel, J.; Sebald, W. Isolation of recombinant BMP receptor IA ectodomain and its 2:1 complex with BMP-2. FEBS Lett. 2000, 468, 215-219. [CrossRef] 
33. Jensen, E.B.; Carlsen, S. Production of recombinant human growth hormone in Escherichia coli: Expression of different precursors and physiological effects of glucose, acetate and salts. Biotech. Bioengin. 1990, 36, 1-11. [CrossRef] [PubMed]

34. Kilkenny, C.; Browne, W.J.; Cuthill, I.C.; Emerson, M.; Altman, D.G. Improving bioscience research reporting: The ARRIVE guidelines for reporting animal research. Osteoarthr. Cartil. 2012, 20, 256-260. [CrossRef] [PubMed]

35. Nakamura, T.; Shirakata, Y.; Shinohara, Y.; Miron, R.J.; Hasegawa-Nakamura, K.; Fujioka-Kobayashi, M.; Noguchi, K. Comparison of the effects of recombinant human bone morphogenetic protein-2 and -9 on bone formation in rat calvarial critical-size defects. Clin. Oral Investig. 2017, 21, 2671-2679. [CrossRef]

36. Stokovic, T.; Ivanjko, N.; Maticic, D.; Luyten, F.P.; Vukicevik, S. Bone morphogenetic proteins, carriers, and animal models in the development of novel bone regenerative therapies. Materials 2021, 14, 3513. [CrossRef]

37. Donos, N.; Lang, N.P.; Karoussis, I.K.; Bosshardt, D.; Tonetti, M.; Kostopoulos, L. Effect of GBR in combination with deproteinized bovine bone mineral and/or enamel matrix proteins on the healing of critical-size defects. Clin. Oral Implants Res. 2004, 15, 101-111. [CrossRef]

38. Luvizuto, E.R.; Tangl, S.; Zanoni, G.; Okamoto, T.; Sonoda, C.K.; Gruber, R.; Okamoto, R. The effect of BMP-2 on the osteoconductive properties of $\beta$-tricalcium phosphate in rat calvaria defects. Biomaterials 2011, 32, 3855-3861. [CrossRef]

39. Shinohara, Y.; Nakamura, T.; Shirakata, Y.; Noguchi, K. Bone healing capabilities of recombinant human bone morphogenetic protein-9 (rhBMP-9) with a chitosan or collagen carrier in rat calvarial defects. Dent. Mater. J. 2016, 35, 454-460. [CrossRef]

40. Vajgel, A.; Mardas, N.; Farias, B.C.; Petrie, A.; Cimões, R.; Donos, N. A systematic review on the critical size defect model. Clin. Oral Implant. Res. 2014, 25, 879-893. [CrossRef]

41. Quaas, B.; Burmeister, L.; Li, Z.; Satalov, A.; Behrens, P.; Hoffmann, A.; Rinas, U. Stability and biological activity of E. coli-derived soluble and precipitated bone morphogenetic protein-2. Pharm. Res. 2019, 36, 184. [CrossRef] [PubMed] 